\title{
LINGUAGENS UMA PROPOSTA PARA O ENSINO DE PRODUÇÃO DE indice TEXTO
}

\section{Dioni Maria dos Santos Paz}

Todos sabem que o ensino da produção de texto representa um grave problema para os professores de Língua Portuguesa das escolas de $1^{\circ}$ e $2^{\circ}$ graus. Estes, depois de inúmeras tentativas, sem resultados satisfatórios, muitas vezes ficam sem perspectivas sobre como ensinar redação. Tal constatação, geralmente, está relacionada à observação do produto final do aluno, isto é, da concretização de um texto dentro de um determinado gênero textual, sem a preocupação com o processo de elaboração como um passo muito importante para a boa execução de um texto.

Diante disso, fica sempre a pergunta do que fazer para ter um rendimento escolar melhor nas aulas de redação. É oportuno esclarecer que há vários gêneros textuais e várias atividades a serem contempladas com a competência comunicativa, porém quero passar a certeza de que com estratégias didático-pedagógicas conscientes fica mais fácil chegarmos onde queremos: ensinar a produzir textos coerentes, bem organizados, harmoniosos, claros e precisos.

Por essas razões, o professor precisa estar ciente de que seu papel consiste em desenvolver vários propósitos: estimular a participação do aluno através da leitura de outros textos; tornar o aluno crítico e eficiente, capaz de melhorar o seu desempenho redacional; possibilitar ao aluno a consciência de que o fato de escrever exige escolhas lógicas; apresentar e sistematizar alguns critérios responsáveis pela tessitura de um texto, como a coerência, a coesão e a informatividade textuais, salientando a progressão das idéias, a não-contradição e a relação entre elas.

Nossa proposta sugere que o professor amplie sua concepção de aula de redação, isto é, as fontes de material para o trabalho em sala de aula devem ser, também, os próprios alunos, incluindo seus conhecimentos lingüísticos e competência comunicativa. Para evitar que surjam caminhos que não são os que queremos e também para não chegar a resultados frustrantes, achamos conveniente delinear alguns aspectos do processo de produção de texto, mostrando uma forma bem acessível de produção e avaliação com resultados que consideramos imediatos.

A metodologia escolhida está fundamentada em SERAFINI(1992), que deixa bem claro que há três razões para utilizar os alunos na correção de textos: a primeira é que em geral eles são mais críticos e juízes que produtores de texto; a segunda é que a correção feita pelos colegas é um excelente estímulo à escrita; a terceira é que a correção entre colegas permite entre eles um diálogo que é muito 


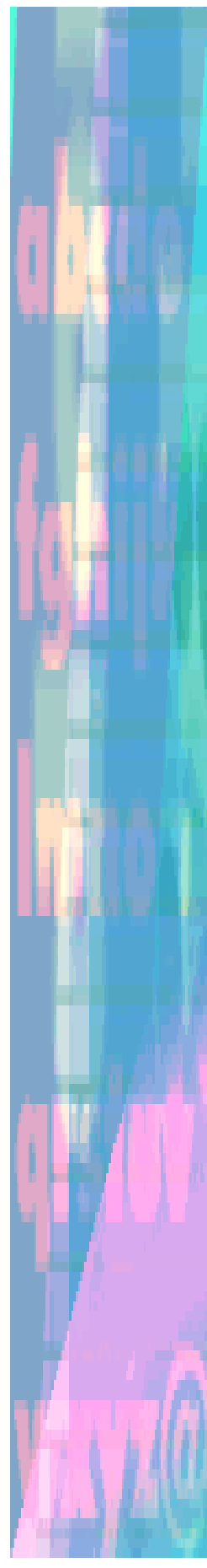

limitado na relação aluno-professor. Dessa forma, a correção interativa permite que o autor do texto explique ao colega e para si mesmo aquilo que pretende expressar.

É possível organizarmos esse tipo de avaliação da seguinte forma:

$1^{0}$ Leitura de um texto com análise da coesão, coerência, intencionalidade, informatividade e aceitabilidade textuais;

$2^{\circ}$ Seleção coletiva das idéias principais;

$3^{\circ}$ Elaboração individual de um novo texto, enfocando o mesmo tema, com enfoques iguais ou diferentes, observando os critérios de correção oferecidos;

$4^{0}$ Troca das redações entre os colegas para que façam uma correção atenta e criteriosa;

$5^{\circ}$ Entrega para o(a) professor(a) que vai fotocopiar a redação preliminarmente corrigida;

$6^{\circ}$ Avaliação escrita, feita pelo professor, das correções feitas pelos alunos;

$7^{\circ}$ Avaliação oral e no quadro, feita pelo professor e alunos, de alguns trechos melhores ou piores, observando os critérios já conhecidos.

$8^{\circ}$ Reescrita da redação pelo primeiro autor do texto;

$9^{\circ}$ Avaliação final feita pelo professor.

À primeira vista, esta metodologia parece dar muito trabalho ao professor, mas não é assim. Lançando-se mão da estratégia da correção interativa, aguça-se a curiosidade do aluno pela interação comunicativa como algo que possibilite troca de conhecimento e experiências. Em pouco tempo, torna-se um mecanismo prazeroso, pois os resultados positivos logo aparecem.

Nossa investigação deixa bem claro que se pretende privilegiar a abordagem da escrita como processo, e, sendo assim, é preciso entender o texto como fruto de um trabalho que implica reflexão sobre a linguagem e conhecimento sobre a constituição e funcionamento da língua.

A proposta feita aqui procura mostrar aos professores que o que se deve fazer é principalmente um ensino produtivo para a aquisição de novas habilidades lingüísticas e para o desenvolvimento do prazer e da competência de escrever. Acredita-se, então, que se possa avançar no estudo do processo / produto da produção textual como fenômenos observáveis. 
Agradecemos ao professor o proveito que fizer dessas idéias em seu trabalho como profissional competente e sério, engajado nas lutas educacionais e preocupado com o êxito de seus alunos e a produtividade de suas aulas.

BIBLIOGRAFIA:

BEAUGRANDE,R.; DRESSLER, W.U. Introduction to text linguistics. London / New York: Longman, 1981.

FÁVERO, L. L.; KOCH, I.G.V. Lingüística textual: Introdução. São Paulo: Cortez, 1983.

GARCIA, O.M. Comunicação em prosa moderna. Rio de Janeiro: Fundação Getúlio Vargas, 1982.

KATO, M. A. No mundo da escrita. São Paulo: Ática, 1986.

KOCH, I. G. V. Argumentação e linguagem. São Paulo: Cortez, 1987.

KOCH, I. G. V. e TRAVAGLIA, L. C. Texto e coerência. São Paulo: Cortez, 1989.

_. A coesão textual. São Paulo: Contexto, 1989.

_. A coerência textual. São Paulo: Contexto, 1991.

MARCUSCHI, L.A. Lingüística do texto: o que é e como se faz. Recife: UFPE, 1983.

SERAFINI, M. T. Como escrever textos. São Paulo: Globo, 1989.

[índice] [ resumo ] 